\title{
A step-by-step overview of the dynamic process of epitope selection by major histocompatibility complex class II for
} presentation to helper T cells [version 1; peer review: 4 approved]

\author{
Scheherazade Sadegh-Nasseri
}

Department of Pathology, Johns Hopkins University School of Medicine, Baltimore, Maryland, 21205, USA

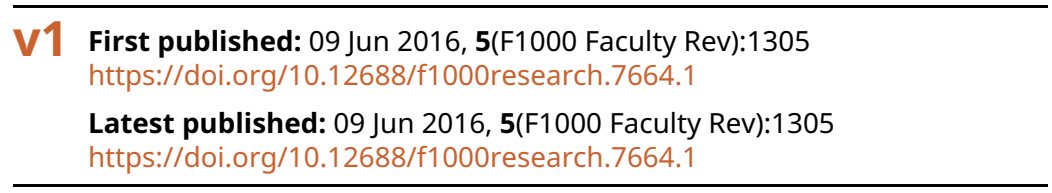

\section{Abstract}

T cell antigen receptors (TCRs) expressed on cytotoxic or helper T cells can only see their specific target antigen as short sequences of peptides bound to the groove of proteins of major histocompatibility complex (MHC) class I, and class II respectively. In addition to the many steps, several participating proteins, and multiple cellular compartments involved in the processing of antigens, the MHC structure, with its dynamic and flexible groove, has perfectly evolved as the underlying instrument for epitope selection. In this review, I have taken a step-by-step, and rather historical, view to describe antigen processing and determinant selection, as we understand it today, all based on decades of intense research by hundreds of laboratories.

\section{Keywords}

Epitope Mapping , Antigen Processing Machinery, immunodominance
Open Peer Review

Approval Status

1

23

34

version 1

09 Jun 2016

Faculty Reviews are review articles written by the prestigious Members of Faculty Opinions. The articles are commissioned and peer reviewed before publication to ensure that the final, published version is comprehensive and accessible. The reviewers who approved the final version are listed with their names and affiliations.

1. Malini Raghavan (D), University of Michigan Medical School, Ann Arbor, USA

2. Nilabh Shastri, University of California, Berkeley, USA

3. Bénédicte Manoury, Université Paris Descartes, Sorbonne Paris Cité, Paris, France

4. Laura Santambrogio, Albert Einstein College of Medicine, New York, USA

Albert Einstein College of Medicine, New 


\section{York, USA}

Any comments on the article can be found at the end of the article.

Corresponding author: Scheherazade Sadegh-Nasseri (ssadegh@jhmi.edu)

Competing interests: The author declares that she has no competing interests.

Grant information: Supported by grants R01AI063764 and R21 AI101987 from NIAID, NIH.

The funders had no role in study design, data collection and analysis, decision to publish, or preparation of the manuscript.

Copyright: @ 2016 Sadegh-Nasseri S. This is an open access article distributed under the terms of the Creative Commons Attribution License, which permits unrestricted use, distribution, and reproduction in any medium, provided the original work is properly cited.

How to cite this article: Sadegh-Nasseri S. A step-by-step overview of the dynamic process of epitope selection by major histocompatibility complex class II for presentation to helper T cells [version 1; peer review: 4 approved] F1000Research 2016, 5 (F1000 Faculty Rev):1305 https://doi.org/10.12688/f1000research.7664.1

First published: 09 Jun 2016, 5(F1000 Faculty Rev):1305 https://doi.org/10.12688/f1000research.7664.1 


\section{Introduction}

$\mathrm{T}$ cells and $\mathrm{B}$ cells are two major components of the adaptive and specific immune system. While B cells can recognize antigens as a whole via their B cell receptors, T cells can only see a processed form of antigens, that is, short peptide sequences bound to the proteins of major histocompatibility complex (MHC) class I and class II. There are also two major classes of $\mathrm{T}$ cells: cytotoxic $\mathrm{T}$ cells $(\mathrm{Tc})$, which are restricted to MHC class I, express CD8 accessory molecules on their cell membranes, and function by killing their targets, and helper $\mathrm{T}$ cells, identified by restriction to MHC class II and expression of CD4 accessory molecules. Helper $\mathrm{T}$ cells function by producing cytokines that help B cells in antibody production and isotype switching, as well as helping $\mathrm{CD}^{+} \mathrm{T}$ cells to develop into memory cells. Helper $\mathrm{T}$ cells are divided into several subclasses, each having different functions ${ }^{1}$. $\mathrm{CD}^{+} \mathrm{T}$ cells are generally responsive to antigens such as viruses which have been endogenously expressed, while helper $\mathrm{T}$ cells present antigens taken up from exogenous sources. The machinery that best generates short peptides that bind to MHC molecules is present in antigen-presenting cells (APC). While a variety of cells might be able to process antigens under certain circumstances, dendritic cells (DC), B cells, and macrophages are considered professional APCs. Antigen processing for presentation by MHC class I follows a different biosynthetic pathway than that of $\mathrm{MHC}$ class $\mathrm{II}^{2,3}$. In the following sections, I focus on MHC class II, discussing different aspects of epitope generation and selection as assisted by the accessory molecules and processing enzymes that allow flawless completion of this complex process. At the end, I will briefly review attempts at identifying peptides that bind MHC molecules.

\section{MHC molecules have optimal structures for presenting antigens}

For the presentation of antigen to helper T cells, APC must achieve an ambitious goal. One or few epitopes from a given antigen must be selected to fit stably and specifically in the groove of MHC class II. However, the number of possible epitopes to bind each MHC molecule is infinite, while each individual carries a maximum of six to eight MHC class II alleles. How is it possible for those few MHC molecules to bind peptides stably but nonspecifically? The crystal structure of MHC class II, HLA-DR ${ }^{4}$, revealed two sets of interactions with the bound peptide: side chains of peptides interacting with five pockets (pockets 1, 4, 6, 7, and 9 ), and a series of $13 \mathrm{H}$-bonds that formed between peptide main chains and the non-polymorphic residues of the MHC groove. It appears that by adopting a combination of pockets that accommodate peptide side chains, the MHC molecule meets the specificity criterion, and by forming H-bonds, complex stability can be achieved.

The next challenging demand from the MHC class II structure is to ensure that peptides from the exogenous antigens bind to the groove of MHC II efficiently. The solution here is provided by evolving a peptide-binding groove that is highly flexible and susceptible to collapsing in the absence of a bound peptide ${ }^{5-7}$. I will write more about this topic later.
Resistance to SDS-mediated denaturation as a means of detecting peptide binding in vivo

The flexibility of the groove is a theme that I shall revisit throughout this review. To appreciate this concept, the readers of this review are likely to benefit from a brief history of peptide binding to MHC class II as part of its folding. Harden McConnell's group was the first to realize that there were kinetic and structural intermediates in peptide binding to MHC $\mathrm{II}^{8-11}$. Using a simple SDS-PAGE assay where samples were kept at room temperature, the team demonstrated that naturally formed peptide/MHC (pMHC) complexes, purified from APC, migrated differently if peptides were dissociated. A loosely bound $\mathrm{pMHC}$, or a peptide free $\mathrm{MHC}$ molecule, migrated as a slower migrating species that was named floppy dimers, relative to a faster migrating species called compact dimers. Compact dimers were shown to contain peptide, and unstably bound pMHC dissociated into single chains in SDSPAGE (SDS sensitive) ${ }^{10,11}$. Importantly, when peptides that could form stable complexes with MHC II molecules were added back to MHC II, the partially unfolded floppy dimers and the dissociated chains reverted to compact conformations ${ }^{6,7}$. It was of great significance that the in vitro findings were confirmed in cells. In pulsechase experiments, analyzed by SDS-PAGE, newly synthesized MHC II molecules that were not in complex with peptides from exogenous sources (pulse) dissociated into single chains, whereas MHC class II molecules that had formed complexes with exogenous peptides (chase) migrated as SDS-stable dimers ${ }^{12,13}$. By this criterion, class II molecules were shown to associate with peptides in the endocytic route prior to cell surface expression, a process that requires proteolytic digestion of the protein antigens ${ }^{13}$. It was also shown that SDS stability did not always correlate with the stability of pMHC complexes; altered MHC mutants bound peptides loosely yet formed the characteristic SDS-stable conformation ${ }^{14}$. Those original observations have been confirmed through numerous techniques over two decades of research by independent laboratories ${ }^{15-19}$.

The remarkable characteristic of MHC class II to resist SDS denaturation when in complex antigenic peptides allowed new discoveries that revealed steps in MHC class II synthesis, association with invariant chain (Ii), exposure to antigen-processing enzymes, MHC II trafficking, interaction with accessory molecules, peptide binding and editing, and more, as discussed below.

\section{Antigen-processing machinery}

Antigen presentation to $\mathrm{CD} 4^{+} \mathrm{T}$ cells begins by the uptake of exogenous antigens by APC and their processing by proteolytic enzymes, mainly different cathepsins (Cat). The process involves transfer through a series of vesicular subcompartments containing suitable denaturing environments, a variety of accessory molecules and molecular chaperones, as well as cathepsins ${ }^{20}$. Cathepsins present in processing compartments contribute by cutting and trimming of the protein antigens.

\section{Cathepsins}

Antigen-processing proteases, or cathepsins, are amongst the most significant contributors to antigen processing and act as 
exoproteases, or endopeptidases ${ }^{21}$. Expression levels and the activity of cathepsins are highly regulated in different cell types and activation states. Historically, two main roles have been described for cathepsins in antigen processing: to cleave off Ii and to process protein antigens. A new important function for cathepsins in the selection of immunodominant epitopes has recently been described and will be discussed later ${ }^{22}$. Some of the most extensively studied cathepsins are CatB, CatD, CatL, and CatS $\mathrm{S}^{23-27}$. CatS was reported to be involved in Ii cleavage and antigen processing ${ }^{28-31}$. Recent studies by Kim et al. ${ }^{22}$ using a cell free processing system showed that inclusion of only three cathepsins (CatB, CatH, and CatS) was sufficient to mimic the processing conditions necessary to produce the immunodominant epitopes from several protein antigens. It is of note that cathepsins involved in antigen processing require acidic $\mathrm{pH}$ for their proteolytic function, which itself is highly regulated. Indeed, DC maturation promotes activation of vacuolar proton pumps and enhances lysosomal acidification ${ }^{32}$.

\section{Invariant chain}

Upon synthesis, every allele of the MHC II heterodimers forms complexes with a third nonpolymorphic chain, called class II Ii, which acts as a chaperone in folding among its several other functions. The Ii was first discovered by Jones and McDevitt, and was found to bind to all MHC II alleles ${ }^{33}$. After intense research by numerous laboratories, it became clear that Ii acts as a chaperone for the newly synthesized MHC II ${ }^{34}$. Its structure is rather segmented, each having a different function. Using nuclear magnetic resonance (NMR) techniques, Jasanoff et al. ${ }^{35-37}$ reported that a soluble recombinant Ii in complex with MHC II was mainly disordered except for two regions, one that included a region of 24 amino acids corresponding to the class II-associated Ii peptide (CLIP) and the other which participated in trimerization of the Ii to form nonomeric assemblies. The CLIP region binds in the peptide-binding groove of class II molecules in the endoplasmic reticulum (ER) and remains bound in cleaved form in the peptideloading compartment, where the rest of the Ii is cleaved off by cathepsins ${ }^{38-41}$. Another important function of Ii is to target the newly synthesized MHC class II to the proper endocytic compartments ${ }^{42}$, where it intercepts with protein antigens. The specialized endosomal compartments, called MIIC or CIIV ${ }^{43-47}$, were discovered as lysosome-like compartments which contained all necessary machinery for the processing of antigen and the optimal binding and selection of the peptides for presentation to the $\mathrm{T}$ cells ${ }^{48}$. These vesicles are dense membranous structures that fall between the early endosomes and lysosomes in density, as well as their denaturing environment to include acidic $\mathrm{pH}^{49}$, denaturing and proteolytic enzymes.

In addition to its other chaperoning functions, binding of Ii to MHC II was originally considered a means of preventing unproductive binding of peptides present in the $\mathrm{ER}^{39}$. However, when the first Ii knockout mice were reported, it turned out that the MHC II molecules of Ii-deficient mice did not bind as many peptides as did the MHC II molecules of Ii-sufficient mice ${ }^{50,51}$. With better understanding of the flexibility and instability of the peptidebinding groove in the absence of a bound peptide ${ }^{52-56}$, it became clear that an unappreciated function of the CLIP region is that it acts as a surrogate peptide for shaping the MHC II groove. These studies demonstrated that the MHC class II groove collapses in the absence of a bound peptide and that a poor binding peptide, such as CLIP, maintains the groove in proper conformation. Upon dissociation of CLIP, a peptide-receptive conformation is generated that can scan peptides or unfolded proteins in the antigen-processing compartments $^{55,56}$. Ii shuttles the MHC II molecules to MIIC, where Ii is proteolyzed by different cathepsins, including CatS, until only the CLIP fragment remains bound in the MHC II peptidebinding groove ${ }^{26,31,57,58}$. CLIP must then be exchanged for exogenous peptide, a function best performed by the accessory molecule HLA-DM in humans or H2-M in mice (DM, from now on) ${ }^{59}$.

\section{HLA-DM}

$\mathrm{DM}$ is a non-polymorphic MHC II-like molecule that does not bind peptides itself ${ }^{60}$ but is necessary for the efficient displacement of CLIP from the MHC groove ${ }^{59,61-69}$. The significance of DM in antigen presentation was first discovered through the observation that some APC lines did not process protein antigens for presentation to specific T cells. Those cell lines were found to have defective DM genes ${ }^{70}$. Later, it was discovered that HLA-DR molecules from an antigen-processing mutant cell line were occupied with invariant chain peptides ${ }^{61,71}$. Hence DM was critical for the removal of CLIP and its exchange for the exogenous peptides.

Mechanism of DM function. Understanding the mechanism of the function of DM posed a problem for a long period of time, as it was generally believed that DM dissociated all bound peptides from MHC II molecules. This concept created a dilemma: how could any peptide remain bound in the groove of MHC II when every peptide was susceptible to dissociation? The problem was partially solved by the finding that not all peptides were equally susceptible to DM-mediated dissociation ${ }^{72,73}$. Certain peptides that would fit the MHC II groove and formed a rather rigid or compact conformation remained resistant to DM-mediated dissociation ${ }^{74-84}$. It was proposed that DM functions by recognizing conformations of pMHC II complexes that vary based on the nature of the bound peptides. For the best-studied MHC II molecule, HLA-DR1, it is well established that P1 interaction is the key determinant of pMHC II complex stability ${ }^{14,52,85}$ and that peptides interacting non-optimally in the P1 pocket are highly susceptible to DM-mediated peptide exchange ${ }^{15,74,75,80,82,86,87}$. DM interaction induces major conformational alterations in the P1 area of the MHC II groove, leading to destabilization of the bound peptide and preventing the formation of $\mathrm{H}$-bonds, hence peptide dissociation. When peptide is released, a peptide-receptive MHC II is generated ${ }^{74,86}$, which can quickly sample a large pool of sequences from the available proteins.

The significance of P1 in interaction with DR1 was demonstrated by a mutagenized DR1 that expressed a partially filled P1 pocket and failed to interact with $\mathrm{DM}^{15,74,82}$. The mutant molecule, DR1(bG81Y), carrying a single amino acid change from $G$ to $Y$, was constitutively peptide receptive and migrated as compact dimers in gentle SDS-PAGE (Figure 1). Indeed, the DR1(bG81Y) molecule resembled murine $\mathrm{I}-\mathrm{E}^{\mathrm{k}}$, which has a shallow pocket $1^{15}$ and itself is resistant to the DM editing function. In agreement with the structural characteristics of I-E $\mathrm{E}^{\mathrm{k}}$, DM knockout haplotype $\mathrm{K}$ mice did not show the characteristic defects in peptide binding and occupancy with CLIP associated with $\mathrm{H}-2^{\mathrm{b}}$ mice $^{88}$. Thus, DM can only affect peptide exchange in MHC II alleles of certain structural requirements ${ }^{89}$. 

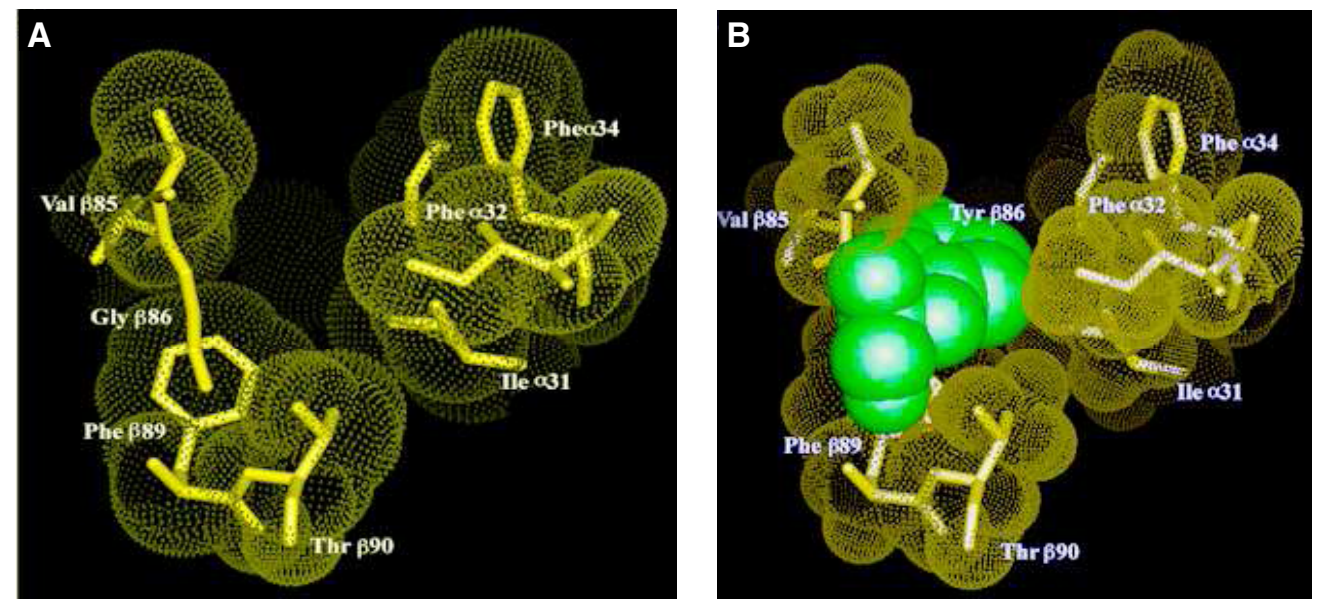

- $D R 1(\beta G 86 Y)$ has a filled P1 pocket

- DR1( $\beta G 86 \mathrm{Y})$ is always in a Peptide-Receptive conformation

- $\mathrm{DR} 1(\beta \mathrm{G} 86 \mathrm{Y})$ is DM-insensitive

Figure 1. DR1(BG86Y) is always in a peptide-receptive conformation. Substitution of glycine for tyrosine at position 86 of DR1 beta chain generates a $\mathrm{P} 1$ pocket that is partially filled and resistant to DM-induced effects ${ }^{14}$.

With the solution of the crystal structure of the DM/DR complex using a cleverly designed DR1/peptide complex that allowed for the DR1 groove to remain open, it was established that DM would bind the P1 pocket of HLA-DR molecules if empty and would remain bound until a $\mathrm{P} 1$ filling peptide bound the groove ${ }^{17,84,90}$. The above findings were complemented by the measured thermodynamics of peptide binding to DR1, indicating that a greater entropic penalty, versus a smaller penalty, was associated with structural rigidity rather than with the flexibility of the pMHC complexes ${ }^{87}$. Consistent with the previous reports, the authors found that DM senses flexible complexes, in which the $\mathrm{P} 1$ area residues are rearranged at a higher frequency than in more rigid complexes. Moreover, a new and unexpected observation reported that conformational changes in the $\mathrm{P} 1$ area could be negated if the $\mathrm{P} 9$ pocket anchor residue of peptide was substituted for a stronger binding residue $^{16}$. The findings suggest that an overall dynamic MHC II conformation, in addition to $\mathrm{P} 1$ pocket occupancy, determines susceptibility to HLA-DM-mediated peptide exchange and provides a molecular mechanism for HLA-DM to efficiently target poorly fitting pMHC II complexes, editing them for more stable ones. Hence, in addition to the removal of CLIP, DM helps in shaping epitope selection (more details to follow).

Biological significance of DM. As discussed earlier, DM plays an important role in selecting the right peptides that can stay in the groove of MHC II long enough for T cell recognition ${ }^{91}$. This characteristic of DM contributes to $\mathrm{T}$ cell immunity in a significant way. Lymphocytes usually respond to a small proportion of the potential determinants on a protein antigen defined as "immunodominant" $"$. Immunodominant epitopes are the essential targets of the immune response against infectious diseases, cancer, autoimmune diseases, and allergy. Consequently, much attention has been devoted to the understanding of epitope selection and immunodominance. However, in spite of the complexities of antigen processing and presentation, $\mathrm{T}$ cell epitope discovery has been a challenging task. Some of the factors contributing to immunodominance are described below.

Epitope accessibility and its relation to immunodominance. Among many contributing factors to an epitope gaining immunodominance is how accessible the location of sequence is to the groove of the MHC II molecule and/or to the processing enzymes ${ }^{93}$. The denaturing environment in the antigen processing compartments (acidic $\mathrm{pH}$ and reducing conditions) helps to partially unfold protein antigens to reveal hidden epitopes. Of particular interest is a specialized enzyme, gamma-interferon-inducible lysosomal thiol reductase (GILT), that releases disulfide bonds in proteins ${ }^{94}$, making denaturation more efficient. In support of the significance of GILT in the release of dominant epitopes is the fact that GILTdeficient mice failed to present buried determinants of hen egg lysozyme (HEL) and an HA protein of influenza; HEL and HA both have four disulfide bonds ${ }^{95,96}$. Support of the "epitope accessibility" model for immunodominance comes from accumulated evidence that many of the naturally selected epitopes localize on flexible strands of protein antigens ${ }^{93}$ or at the C- or N-terminus of protein antigens ${ }^{97-99}$. For a more comprehensive review on the subject of accessibility, the readers are referred to 102 .

One question that might come to the mind of readers is how is it that the MHC II and their accessory molecules are not denatured 
in such an aggressive environment? It is of note that acidification of the antigen processing compartments in DC is developmentally regulated. Hence, the vacuolar proton pump that acidifies MIIC and activates cathepsins for processing of internalized antigens is activated only upon DC maturation ${ }^{32}$. Also of importance is that MHC II and DM molecules resist denaturation and cleavage ${ }^{100}$ by the harsh acidic $\mathrm{pH}$ and proteolytic conditions likely present in the late endosomes.

A cell free reductionist antigen processing system. A need for epitope accessibility together with the open-ended groove of $\mathrm{MHC}$ class II hint at binding of MHC II to the whole antigen rather than precut peptides. While there have been several examples of MHC II binding to full length antigens ${ }^{101-103}$, the prevailing dogma assumes that peptides are cut first, and then binding to MHC II and selection by DM takes place ${ }^{104}$. However, direct evidence in support of binding of full length protein to MHC II and determinant selection by DM was put forth by the design and use of a reductionist cell free antigen processing system, which documented that full-length proteins, or a mixture of protein fragments, could be processed and the immunodominant epitopes could be selected by a minimal number of ingredients ${ }^{100}$ (Figure 2). The components of this minimalist system include MHC class II, HLA-DR, full-length denatured protein antigen, three processing enzymes, cathepsins $\mathrm{S}$ (an endopeptidase), B, and $\mathrm{H}$ (exopeptidases), and HLA-DM, all placed in a tube in acidic $\mathrm{pH}$. After allowing time for processing of the antigen, peptide binding, and DM editing, DR molecules, now bound to the selected epitopes, are immunoprecipitated and the bound peptides are released by exposure to low $\mathrm{pH}$ and are then subjected to mass spectrometry. In the following steps, the identified peptides, which usually are not very many, will be tested for immunogenicity in HLA-DR1-expressing Tg mice immunized with the full-length protein antigens. The results were quite pleasing: peptides identified by the reductionist system were immunodominant epitopes because they recalled nearly full $\mathrm{T}$ cell responses. Importantly, even when tested in human volunteers, the peptides identified by the reductionist system proved to accurately reflect antigen processing in human $\mathrm{APCs}^{100}$. It is significant that the immunodominant epitopes were identified when DM was included in the system whereas, in the absence of DM, other nondominant epitopes were also found among the eluted peptides.

The results from the reductionist system suggested that DM plays a key role in the selection of the immunodominant epitopes from exogenous antigens $22,100,105,106$. In a later extensive study, Yin et al. compared affinity, intrinsic dissociation half-life, and DM-mediated dissociation half-life as well as two epitope prediction algorithms (more below) for many peptides derived from the

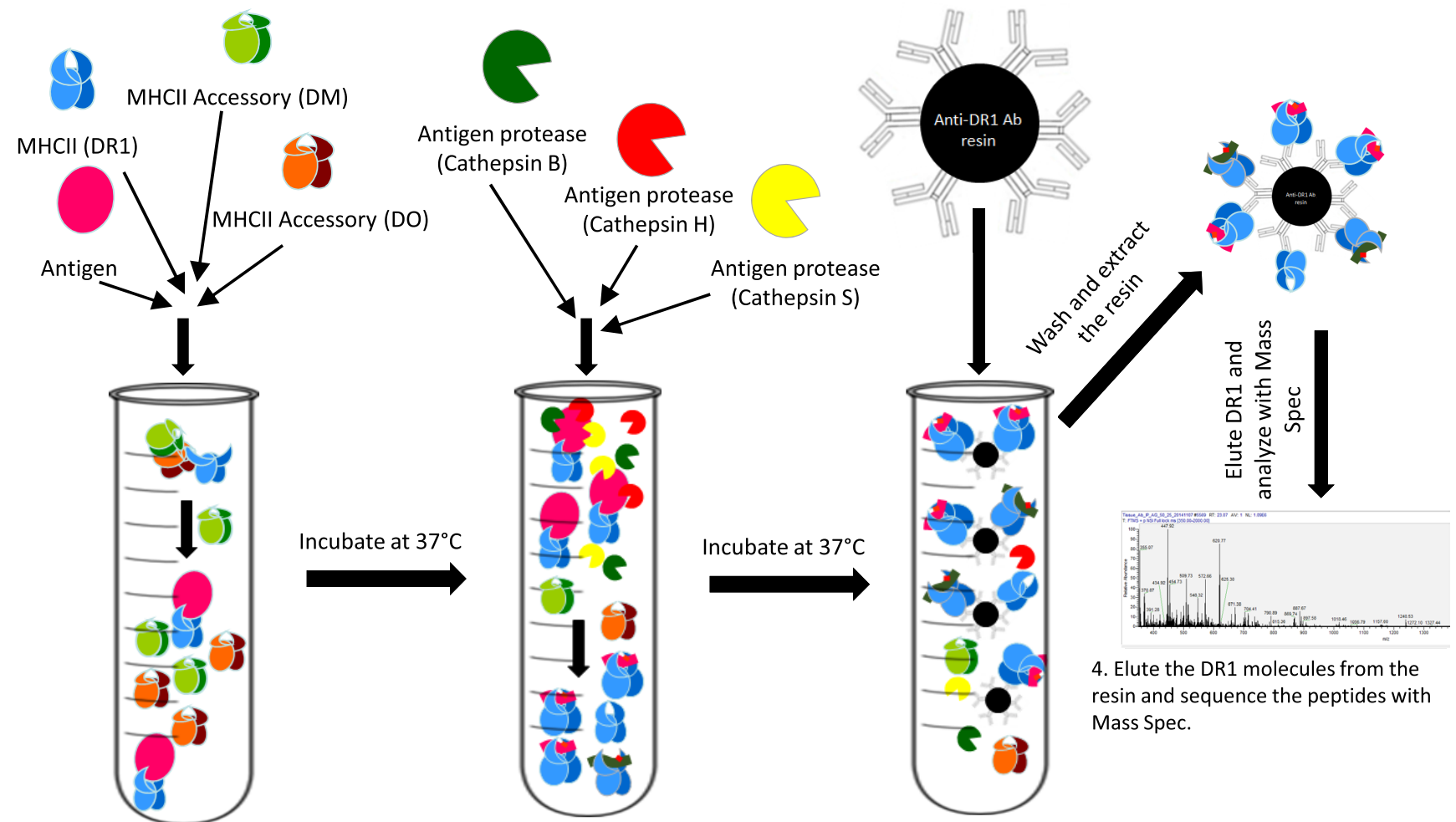

1. Allow the full antigenic protein to bind to the MHC II molecule with the help of accessory molecules DM or DM/DO.
2. Use Cathepsins to digest away the full length antigen leaving behind only the immunodominant peptides bound to DR1 molecules.
3. Purify the DR1 molecules with bound peptides from the other cell-free system components through immunoprecipitation.

Figure 2. A reductionist cell free antigen processing system. Purified MHC class II and accessory molecules are exposed to full-length antigens and cathepsins under denaturing conditions. MHC class II molecules are then isolated and subjected to peptide elution and mass spectrometry ${ }^{100}$. 
entire Vaccinia genome for inducing $\mathrm{CD}^{+} \mathrm{T}$ cell responses. The results confirmed that pMHC II complex kinetic stability in the presence of DM was the determining factor for distinguishing the immunodominant epitopes from the non-dominant bound peptides $^{107}$. In agreement with results from the reductionist system, these analyses demonstrated that DM editing governs peptide immunogenicity by favoring the presentation of peptides with greater kinetic stability. However, it is of note that not all stable pMHC complexes are immunodominant. Moreover, autoimmune epitopes may or may not be resistant to DM-mediated dissociation ${ }^{22}$.

The use of the cell free reductionist system also enabled the authors to gain a new understanding of dominant epitope selection $22,105,106,108$. The authors showed that peptides derived from pathogens, or autoantigens, behaved differently in response to DM. For autoantigens, resistance to DM-mediated dissociation was not a required criterion, whereas for pathogen-derived dominant epitopes, DM resistance was a crucial factor. Immunodominance emerged as a result of the combined effects of DM and the antigen processing cathepsins. Autoantigen-derived immunodominant epitopes were resistant to digestion by cathepsins in the system, whereas pathogen-derived epitopes were sensitive. As such, sensitivity to cathepsins necessitated the capture of pathogenderived epitopes by MHC II prior to cathepsins processing, and resistance to DM-mediated-dissociation preserved those epitopes from $\mathrm{pMHC}$ release and degradation ${ }^{22}$. The overall findings demonstrated that immunodominance is established by the higher relative abundance of the selected epitopes that survive cathepsins digestion either by binding to MHC II and resisting DM-mediateddissociation or by being chemically resistant to cathepsin degradation. Non-dominant epitopes were found to be sensitive to both DM and cathepsins ${ }^{22}$ (Figure 3). Consistent with the autoimmune epitopes being resistant to proteolysis is the finding that large numbers of peptides derived from autoantigens have been identified in normal pre-nodal afferent human lymph ${ }^{109,110}$. The lymph peptidome must have resisted the variety of catabolic enzymes present in tissues, the function of which remains to be understood.

Possible role of DM in the quality of the peptide/MHC II complex. Intriguingly, there are reports documenting that some autoimmune $\mathrm{T}$ cells might discriminate among peptides that form complexes with MHC II in the presence or absence of DM. A clear example has been pioneered by Unanue and colleagues, who showed two types of T cells: type A that recognize pMHC generated by intracellular processing machinery including DM and type $\mathrm{B} T$ cells that recognize pMHC formed in the absence of $\mathrm{DM}^{111,112}$. Of outstanding interest is that autoreactive $\mathrm{CD} 4^{+} \mathrm{T}$ cells specific for an insulin peptide were type B T cells; they did not recognize the insulin protein when processed by APC and, as such, could not have been deleted during thymic education ${ }^{113}$. These findings suggest that the topology of the complexes formed in the presence or absence of DM might be different. The findings of the Unanue and SadeghNasseri laboratories hint at the possibility of a different path for antigen processing for autoimmune epitopes. As discussed, autoimmune epitopes may or may not be sensitive to DM-mediated dissociation, and they are highly resistant to the proteases in antigen processing ${ }^{22}$.
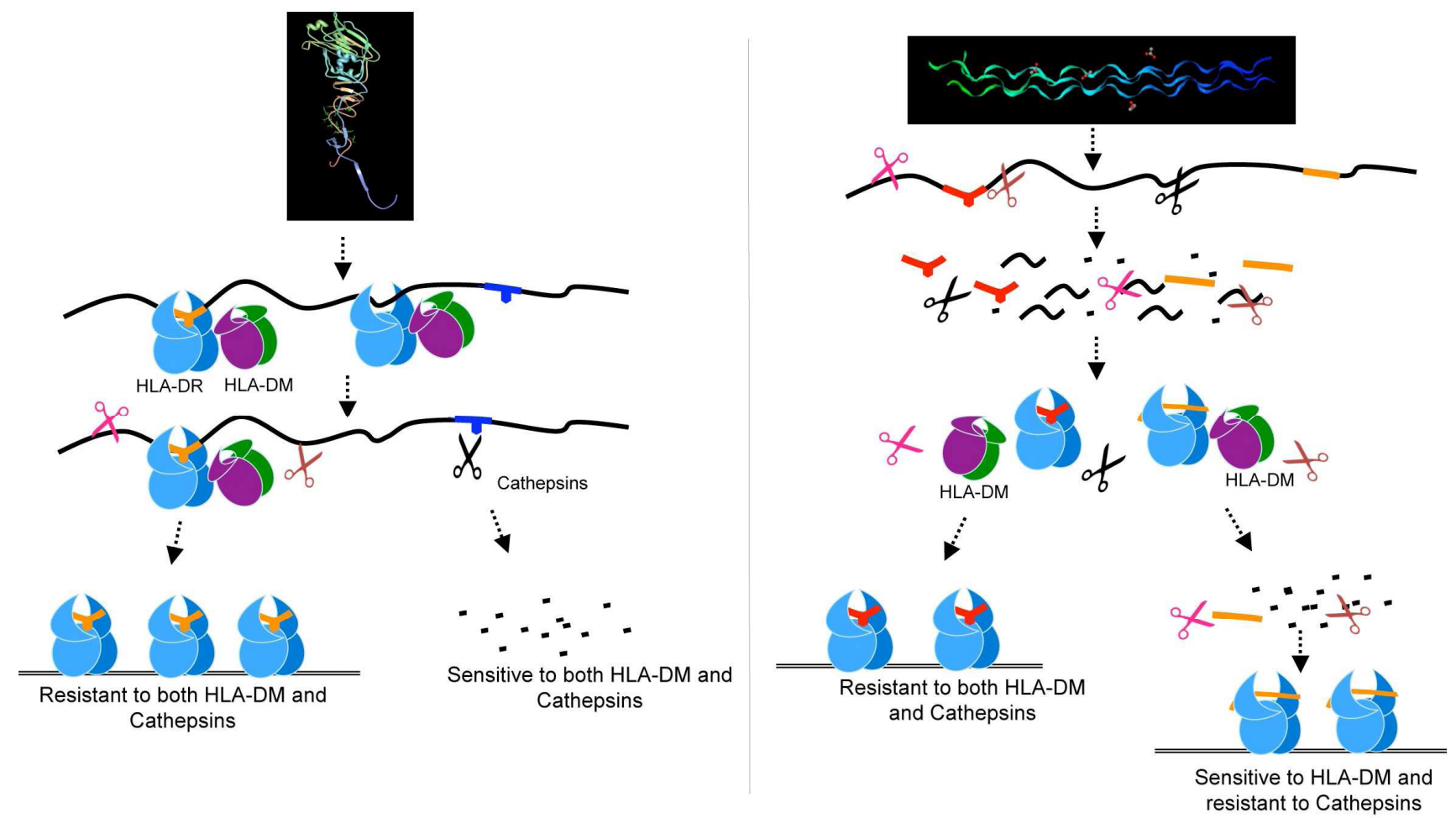

Figure 3. Auto-antigens and pathogen-derived antigens are processed differently. Influenza-derived HA protein (left) is captured as full-length denatured protein or large fragments by MHC class II, edited by DM, and then is exposed to cathepsin digestion. An example of an auto-antigen, collagen (right), is first cut into short peptides and then binds MHC class II; it may be either sensitive or resistant to DM-mediated editing 22 . 
Hence, it is very likely that for some autoimmune diseases, autoantigens are generated in an extracellular matrix where many proteases are already at work. The core epitopes that survive such a protease-rich milieu may get a chance to bind to the empty MHC II molecules expressed on APC membranes or in the early endosomal compartment where DM is not active ${ }^{114}$. Such complexes would not be edited by DM and would fit the required ligand characteristic for type B T cells. Alternatively, some of the larger antigen fragments might be processed in the early endosomes where DM does not contribute to peptide editing, leading to the generation of type B pMHC complexes.

\section{HLA-DO}

In addition to DM, another non-classical MHC class II accessory molecule, HLA-DO, H2-O in mice, DO from now on, is known to play a role in peptide exchange ${ }^{115-117}$. Of importance, DO has restricted tissue expression; it is mainly expressed in B cells and thymic medullary epithelium, where thymic deletion takes place. In addition, certain subsets of DCs express DO under different conditions. Cellular trafficking of DO depends on DM. Understanding how DO contributes to antigen processing has been a challenge for decades. Two recently solved crystal structures, DM/DO and $\mathrm{DM} / \mathrm{DR} 1$, suggested that the DM/DO interface is shared with the DM interface with DR $1^{90,118}$. These findings were interpreted to imply that DO might act as a competitive inhibitor of DM in interaction with DR. While this model has previously been advocated $^{117}$, peptide binding association and dissociation kinetics conducted in the presence of DM, and/or DM/DO, put forward an alternative mechanism ${ }^{115,116}$. It was shown that DO binds to DR molecules. Rather than inhibiting DM, it was demonstrated that DO works together with DM to increase the binding of peptides that formed DM-resistant complexes with DR, while reducing the binding of peptides that are DM sensitive. Furthermore, the positive and negative effects of DO on peptide binding were shown to be restricted to the association phase, as the peptide dissociation phase remained unaffected by DO. Interestingly, DO could only bind to a peptide-receptive rather than peptide-occupied DR1. Because DO is always in complex with DM, and DM works by generating a peptide-receptive conformation, the authors proposed a model to suggest that DM might dissociate pMHC, leading to a peptidereceptive DR that can be stabilized by DO. Thus, DO and DM work in synergy for optimizing peptide exchange and for selecting the DM-resistant peptides. The combined efforts of all the molecules discussed above, and perhaps others whose identities are yet to be discovered, lead to an impeccable selection process for the immunodominant epitopes for MHC II groove occupancy and transport to the APC external membrane for $\mathrm{CD}^{+} \mathrm{T}$ cell stimulation.

\section{Search for the immunodominant epitopes}

Clearly, finding peptide epitopes that bind to MHC molecules and represent a given antigen is highly desirable for use in therapeutics and vaccine designs. A variety of methods have been used for this purpose. Among those is the screening of hundreds of overlapping synthetic peptides that span the entire sequence of an antigen of interest for binding to MHC II molecules. The screening may involve biophysical methods to measure MHC II binding, T cell readout assays, or tetramer-guided epitope mapping. Hundreds of tetramers would be made using hundreds of overlapping peptides for detection of the T cells reactive to the antigen ${ }^{119}$. These methods are generally labor intensive, costly, and often insufficient because, with the exception of tetramer-guided mapping, they do not take into account steps involved in the processing of antigens as it happens in the cellular environment. In the identification of autoimmune epitopes, the task is even more arduous because autoimmune epitopes, in addition to the characteristics discussed above, often include post-translational modifications ${ }^{119}$, which makes screening of the peptides based on the amino acid sequences of the proteins rather hopeless.

\section{Computational approaches and mass spectrometry}

Computational approaches are popular alternative methods for predicting possible epitopes that bind MHC class II molecules with high affinity. The guiding principle in all computational methods is the structural information available on different MHC grooves. Although somewhat successful for predicting $\mathrm{MHC}$ class I epitopes, computer prediction algorithms have been generally unsuccessful in identifying $\mathrm{CD}^{+} \mathrm{T}$ cell epitopes ${ }^{120-122}$. The open-ended MHC class II groove versus the better-defined pocket-fitting residues for MHC class I adds to the complexity of structure-based predictions exponentially. In addition, there is no computational way yet available for predicting how DM and DO would contribute to the epitope selection ${ }^{107}$.

The next popular method in epitope discovery is the use of mass spectrometry. Mass spectrometry for the identification of peptides eluted from MHC class I and class II was first reported in the early $1990 \mathrm{~s}^{123}$ and required large amounts of purified MHC molecules. Thousands of self-peptides are generally eluted from MHC molecules isolated from even uninfected APCs. In recent years, because of the great progress in the development of highly sensitive instruments for mass spectrometry, the need for high quantities of starting numbers of APCs $\left(\sim 10^{11}\right)$ has been significantly reduced ${ }^{124}$. However, for an accurate determination of the dominant epitopes by peptide elution, it is necessary to utilize quantitative mass spectrometry because immunodominant epitopes are often displayed at the highest prevalence ${ }^{22}$, yet quantitative mass spectrometry has its own associated extreme complexities $^{125}$.

\section{Concluding remarks}

As discussed above, antigen processing is a complex multistep process that has evolved for the identification of the best-fitting epitopes for $\mathrm{T}$ cell recognition and functions. A number of chaperones together with the uniquely evolved MHC class II molecular structure, which requires a peptide as part of its fully folded state, contribute to this ultimate goal. While much has been learned over the past decades about antigen processing and presentation, because of the complexities involved, a successful peptide prediction strategy has yet to be discovered. The divergent paths for the processing of proteins of exogenous versus self-antigens open up new fields to explore. Understanding the biology of DO and its effects on the development of autoimmune diseases is another area that has remained challenging. Finally, the expression of MHC II upon T cell activation and its impact on immune responses begs further research. We can only hope that current and future research will focus on these unanswered questions. 
Competing interests

The author declares that she has no competing interests.

\section{Grant information}

Supported by grants R01AI063764 and R21 AI101987 from NIAID, NIH.

The funders had no role in study design, data collection and analysis, decision to publish, or preparation of the manuscript.

\section{Acknowledgements}

I wish to dedicate this review to the memories of my mentors, Eli Sercarz and Harden McConnell, who were instrumental in conceiving and promoting many of the concepts discussed here. In addition, I sincerely thank all of the members of my laboratory whose hard work has led to some of the insights described in this review. Finally, I extend my gratitude to the reviewers of the manuscript who made many good suggestions that led to refining this review.
1. Zhu J, Paul WE: Heterogeneity and plasticity of T helper cells. Cell Res. 2010; 20(1): 4-12.

PubMed Abstract | Publisher Full Text | Free Full Text

2. Neefjes JJ, Stollorz V, Peters PJ, et al.: The biosynthetic pathway of MHC class II but not class I molecules intersects the endocytic route. Cell. 1990; 61(1): $171-83$.

PubMed Abstract | Publisher Full Text

3. Peters PJ, Neefjes JJ, Oorschot V, et al.: Segregation of MHC class II molecules from MHC class I molecules in the Golgi complex for transport to lysosomal compartments. Nature. 1991; 349(6311): 669-76. PubMed Abstract | Publisher Full Text

4. Stern LJ, Brown JH, Jardetzky TS, et al.: Crystal structure of the human class II MHC protein HLA-DR1 complexed with an influenza virus peptide. Nature. 1994; 368(6468): 215-21.

PubMed Abstract | Publisher Full Text

5. Sadegh-Nasseri S, Natarajan S, Chou C, et al:: Conformational heterogeneity of MHC class II induced upon binding to different peptides is a key regulator in antigen presentation and epitope selection. Immunol Res. 2010; 47(1-3): 56-64. PubMed Abstract | Publisher Full Text | Free Full Text

6. Sadegh-Nasseri S, Germain RN: How MHC class II molecules work: peptidedependent completion of protein folding. Immunol Today. 1992; 13(2): 43-6. PubMed Abstract | Publisher Full Text

7. Sadegh-Nasseri S, Germain RN: A role for peptide in determining MHC class II structure. Nature. 1991; 353(6340): 167-70. PubMed Abstract | Publisher Full Text

8. Sadegh-Nasseri S, McConnell HM: A kinetic intermediate in the reaction of an antigenic peptide and I-E'. Nature. 1989; 337(6204): 274-6. PubMed Abstract | Publisher Full Text

9. Tampé R, McConnell HM: Kinetics of antigenic peptide binding to the class II major histocompatibility molecule I-Ad. Proc Natl Acad Sci U S A. 1991; 88(11): 4661-5.

PubMed Abstract | Publisher Full Text | Free Full Text

10. Dornmair K, Rothenhäusler B, McConnell HM: Structural intermediates in the reactions of antigenic peptides with MHC molecules. Cold Spring Harb Symp Quant Biol. 1989; 54(Pt 1): 409-16.

PubMed Abstract | Publisher Full Text

11. Dornmair K, McConnell HM: Refolding and reassembly of separate alpha and beta chains of class II molecules of the major histocompatibility complex leads to increased peptide-binding capacity. Proc Natl Acad Sci U S A. 1990; 87(11): 4134-8.

PubMed Abstract | Publisher Full Text | Free Full Text

12. Germain RN, Hendrix LR: MHC class II structure, occupancy and surface expression determined by post-endoplasmic reticulum antigen binding. Nature. 1991; 353(6340): 134-9. PubMed Abstract | Publisher Full Text

13. Neefjes JJ, Ploegh HL: Inhibition of endosomal proteolytic activity by leupeptin blocks surface expression of MHC class II molecules and their conversion to SDS resistance alpha beta heterodimers in endosomes. EMBO J. 1992; 11(2): 411-6.

PubMed Abstract | Free Full Text

14. Natarajan SK, Stern LJ, Sadegh-Nasseri S: Sodium dodecyl sulfate stability of HLA-DR1 complexes correlates with burial of hydrophobic residues in pocket 1 . J Immunol. 1999; 162(6): 3463-70.

PubMed Abstract
15. Sato AK, Zarutskie JA, Rushe MM, et al: Determinants of the peptide-induced conformational change in the human class II major histocompatibility complex protein HLA-DR1. J Biol Chem. 2000; 275(3): 2165-73. PubMed Abstract | Publisher Full Text

16. F Yin L, Trenh P, Guce A, et al.: Susceptibility to HLA-DM protein is determined by a dynamic conformation of major histocompatibility complex class II molecule bound with peptide. J Biol Chem. 2014; 289(34): 23449-64. PubMed Abstract | Publisher Full Text | Free Full Text | F1000 Recommendation

17. Painter CA, Negroni MP, Kellersberger KA, et al.: Conformational lability in the class II MHC $3_{10}$ helix and adjacent extended strand dictate HLA-DM susceptibility and peptide exchange. Proc Natl Acad Sci U S A. 2011; 108(48): 19329-34.

PubMed Abstract | Publisher Full Text | Free Full Text

18. F Ferrante A, Anderson MW, Klug CS, et al:: HLA-DM mediates epitope selection by a "compare-exchange" mechanism when a potential peptide pool is available. PLoS One. 2008; 3(11): e3722.

PubMed Abstract | Publisher Full Text | Free Full Text | F1000 Recommendation

19. Ferrante A, Gorski J: A Peptide/MHCII conformer generated in the presence of exchange peptide is substrate for HLA-DM editing. Sci Rep. 2012; 2: 386. PubMed Abstract | Publisher Full Text | Free Full Text

20. Blum JS, Wearsch PA, Cresswell P: Pathways of antigen processing. Annu Rev Immunol. 2013; 31: 443-73.

PubMed Abstract | Publisher Full Text | Free Full Text

21. van den Hoorn T, Paul P, Jongsma ML, et al.: Routes to manipulate MHC class II antigen presentation. Curr Opin Immunol. 2011; 23(1): 88-95. PubMed Abstract | Publisher Full Text

22. F Kim A, Hartman IZ, Poore B, et al:: Divergent paths for the selection of immunodominant epitopes from distinct antigenic sources. Nat Commun. 2014; 5: 5369.

PubMed Abstract | Publisher Full Text | Free Full Text | F1000 Recommendation

23. Manoury B: Proteases: essential actors in processing antigens and intracellular toll-like receptors. Front Immunol. 2013; 4: 299. PubMed Abstract | Publisher Full Text | Free Full Text

24. Hsing LC, Rudensky AY: The lysosomal cysteine proteases in MHC class II antigen presentation. Immunol Rev. 2005; 207(1): 229-41. PubMed Abstract | Publisher Full Tex

25. Chapman HA: Endosomal proteases in antigen presentation. Curr Opin Immunol. 2006; 18(1): 78-84. PubMed Abstract | Publisher Full Tex

26. Nakagawa TY Brissette $\mathrm{WH}$, Lira PD, et al: Impaired invariant chain degradation and antigen presentation and diminished collagen-induced arthritis in cathepsin S null mice. Immunity. 1999; 10(2): 207-17. PubMed Abstract | Publisher Full Text

27. Nakagawa $T$, Roth $\mathrm{W}$, Wong $\mathrm{P}$, et al: Cathepsin L: critical role in li degradation and CD4 T cell selection in the thymus. Science. 1998; 280(5362): 450-3. PubMed Abstract | Publisher Full Text

28. Villadangos JA, Ploegh HL: Proteolysis in MHC class II antigen presentation: who's in charge? Immunity. 2000; 12(3): 233-9. PubMed Abstract | Publisher Full Text

29. Honey K, Rudensky AY: Lysosomal cysteine proteases regulate antigen presentation. Nat Rev Immunol. 2003; 3(6): 472-82. PubMed Abstract | Publisher Full Text 
30. Plüger EB, Boes M, Alfonso $\mathrm{C}$, et al:: Specific role for cathepsin $\mathrm{S}$ in the generation of antigenic peptides in vivo. Eur J Immunol. 2002; 32(2): 467-76. PubMed Abstract | Publisher Full Text

31. Riese RJ, Wolf PR, Brömme D, et al.: Essential role for cathepsin S in MHC class II-associated invariant chain processing and peptide loading. Immunity. 1996; 4(4): 357-66

PubMed Abstract | Publisher Full Text

32. F Trombetta ES, Ebersold M, Garrett W, et al: Activation of lysosomal function during dendritic cell maturation. Science. 2003; 299(5611): 1400-3.

PubMed Abstract | Publisher Full Text | F1000 Recommendation

33. Jones PP, Murphy DB, McDevitt HO: Two-gene control of the expression of a murine la antigen. J Exp Med. 1978; 148(4): 925-39. PubMed Abstract | Publisher Full Text | Free Full Text

34. Teyton L, O'Sullivan D, Dickson PW, et al:: Invariant chain distinguishes between the exogenous and endogenous antigen presentation pathways. Nature. 1990; 348(6296): 39-44.

PubMed Abstract | Publisher Full Text

35. Jasanoff $A$, Song $S$, Dinner AR, et al:: One of two unstructured domains of li becomes ordered in complexes with MHC class II molecules. Immunity. 1999; 10(6): 761-8.

PubMed Abstract | Publisher Full Text

36. Jasanoff A, Wagner G, Wiley DC: Structure of a trimeric domain of the MHC class II-associated chaperonin and targeting protein Ii. EMBO J. 1998; 17(23): $6812-8$.

PubMed Abstract | Publisher Full Text | Free Full Text

37. Jasanoff A, Park SJ, Wiley DC: Direct observation of disordered regions in the major histocompatibility complex class II-associated invariant chain. Proc Nat Acad Sci U S A. 1995; 92(21): 9900-4.

PubMed Abstract | Publisher Full Text | Free Full Text

38. Strubin M, Mach B, Long EO: The complete sequence of the mRNA for the HLA-DR-associated invariant chain reveals a polypeptide with an unusual transmembrane polarity. EMBO J. 1984; 3(4): 869-72. PubMed Abstract | Free Full Text

39. Roche PA, Cresswell P: Invariant chain association with HLA-DR molecules inhibits immunogenic peptide binding. Nature. 1990; 345(6276): 615-8. PubMed Abstract | Publisher Full Text

40. Sekaly RP, Tonnelle C, Strubin M, et al:: Cell surface expression of class II histocompatibility antigens occurs in the absence of the invariant chain. $J$ Exp Med. 1986; 164(5): 1490-504.

PubMed Abstract | Publisher Full Text | Free Full Text

41. Park SJ, Sadegh-Nasseri S, Wiley DC: Invariant chain made in Escherichia coli has an exposed $\mathrm{N}$-terminal segment that blocks antigen binding to HLA-DR1 and a trimeric C-terminal segment that binds empty HLA-DR1. Proc Natl Acad Sci U S A. 1995; 92(24): 11289-93.

PubMed Abstract | Publisher Full Text | Free Full Text

42. Lotteau V, Teyton L, Peleraux A, et al:: Intracellular transport of class II MHC molecules directed by invariant chain. Nature. 1990; 348(6302): 600-5. PubMed Abstract | Publisher Full Text

43. West MA, Lucocq JM, Watts C: Antigen processing and class II MHC peptideloading compartments in human B-lymphoblastoid cells. Nature. 1994; 369(6476): 147-51.

PubMed Abstract | Publisher Full Text

44. Tulp A, Verwoerd D, Dobberstein B, et al:: Isolation and characterization of the intracellular MHC class II compartment. Nature. 1994; 369(6476): 120-6. PubMed Abstract | Publisher Full Text

45. Amigorena $\mathrm{S}$, Drake JR, Webster $\mathrm{P}$, et al:: Transient accumulation of new class II MHC molecules in a novel endocytic compartment in B lymphocytes. Nature. 1994; 369(6476): 113-20.

PubMed Abstract | Publisher Full Text

46. Calafat J, Nijenhuis $\mathrm{M}$, Janssen $\mathrm{H}$, et al:: Major histocompatibility complex class II molecules induce the formation of endocytic MIIC-like structures. J Cell Biol. 1994; 126(4): 967-77.

PubMed Abstract | Publisher Full Text | Free Full Text

47. Castellino F, Germain RN: Extensive trafficking of MHC class II-invariant chain complexes in the endocytic pathway and appearance of peptide-loaded class II in multiple compartments. Immunity. 1995; 2(1): 73-88.

PubMed Abstract | Publisher Full Text

48. Sanderson F, Kleijmeer MJ, Kelly A, et al.: Accumulation of HLA-DM, a regulator of antigen presentation, in MHC class II compartments. Science. 1994; 266(5190): 1566-9.

PubMed Abstract | Publisher Full Text

49. Jensen PE: Regulation of antigen presentation by acidic pH. J Exp Med. 1990; 171(5): 1779-84.

PubMed Abstract | Publisher Full Text | Free Full Text

50. Viville S, Neefjes J, Lotteau V, et al:: Mice lacking the MHC class II-associated invariant chain. Cell. 1993; 72(4): 635-48.

PubMed Abstract | Publisher Full Text

51. Zhong G, Castellino F, Romagnoli $P$, et al.: Evidence that binding site occupancy is necessary and sufficient for effective major histocompatibility complex (MHC) class II transport through the secretory pathway redefines the primary function of class II-associated invariant chain peptides (CLIP). J Exp Med. 1996; 184(5): 2061-6.

PubMed Abstract | Publisher Full Text | Free Full Text
52. Stern LJ, Wiley DC: The human class II MHC protein HLA-DR1 assembles as empty alpha beta heterodimers in the absence of antigenic peptide. Cell. 1992; 68(3): 465-77.

PubMed Abstract | Publisher Full Text

53. Germain RN, Rinker AG Jr: Peptide binding inhibits protein aggregation of invariant-chain free class II dimers and promotes surface expression of occupied molecules. Nature. 1993; 363(6431): 725-8.

PubMed Abstract | Publisher Full Text

54. Sadegh-Nasseri S, Stern LJ, Wiley DC, et al.: MHC class II function preserved by low-affinity peptide interactions preceding stable binding. Nature. 1994 370(6491): 647-50

PubMed Abstract | Publisher Full Text

55. Natarajan SK, Assadi M, Sadegh-Nasseri S: Stable peptide binding to MHC class II molecule is rapid and is determined by a receptive conformation shaped by prior association with low affinity peptides. J Immunol. 1999; 162(7): 4030-6. PubMed Abstract

56. Rabinowitz JD, Vrlijic M, Kasson PM, et al:: Formation of a highly peptidereceptive state of class II MHC. Immunity. 1998; 9(5): 699-709. PubMed Abstract | Publisher Full Tex

57. Riese RJ, Mitchell RN, Villadangos JA, et al:: Cathepsin S activity regulates antigen presentation and immunity. J Clin Invest. 1998; 101(11): 2351-63. PubMed Abstract | Publisher Full Text | Free Full Text

58. Driessen C, Bryant RA, Lennon-Duménil AM, et al:: Cathepsin S controls the trafficking and maturation of MHC class II molecules in dendritic cells. J Cell Biol. 1999; 147(4): 775-90.

PubMed Abstract | Publisher Full Text | Free Full Text

59. Morris $\mathrm{P}$, Shaman J, Attaya $\mathrm{M}$, et al:: An essential role for HLA-DM in antigen presentation by class II major histocompatibility molecules. Nature. 1994; 368(6471): 551-4.

PubMed Abstract | Publisher Full Text

60. Mosyak L, Zaller DM, Wiley DC: The structure of HLA-DM, the peptide exchange catalyst that loads antigen onto class II MHC molecules during antigen presentation. Immunity. 1998; 9(3): 377-83.

PubMed Abstract | Publisher Full Text

61. Riberdy JM, Newcomb JR, Surman MJ, et al.: HLA-DR molecules from an antigen-processing mutant cell line are associated with invariant chain peptides. Nature. 1992; 360(6403): 474-7.

PubMed Abstract | Publisher Full Text

62. Denzin LK, Robbins NF, Carboy-Newcomb C, et al:: Assembly and intracellular transport of HLA-DM and correction of the class II antigen-processing defect in T2 cells. Immunity. 1994; 1(7): 595-606.

PubMed Abstract | Publisher Full Text

63. Denzin LK, Cresswell P: HLA-DM induces CLIP dissociation from MHC class II alpha beta dimers and facilitates peptide loading. Cell. 1995; 82(1): 155-65. PubMed Abstract | Publisher Full Text

64. Cresswell P: Invariant chain structure and MHC class II function. Cell. 1996; 84(4): 505-7.

PubMed Abstract | Publisher Full Tex

65. Denzin LK, Hammond C, Cresswell P: HLA-DM interactions with intermediates in HLA-DR maturation and a role for HLA-DM in stabilizing empty HLA-DR molecules. J Exp Med. 1996; 184(6): 2153-65.

PubMed Abstract | Publisher Full Text | Free Full Text

66. Spies $\mathrm{T}$, Bresnahan $\mathrm{M}$, Bahram $\mathrm{S}$, et al.: $\mathbf{A}$ gene in the human major histocompatibility complex class II region controlling the class I antigen presentation pathway. Nature. 1990; 348(6303): 744-7. PubMed Abstract | Publisher Full Text

67. Mellins E, Kempin S, Smith L, et al:: A gene required for class II-restricted antigen presentation maps to the major histocompatibility complex. $J$ Exp Med. 1991; 174(6): 1607-15.

PubMed Abstract | Publisher Full Text | Free Full Text

68. Mellins $\mathrm{E}$, Cameron $\mathrm{P}$, Amaya $\mathrm{M}$, et al:: A mutant human histocompatibility leukocyte antigen DR molecule associated with invariant chain peptides. $J$ Exp Med. 1994; 179(2): 541-9.

PubMed Abstract | Publisher Full Text | Free Full Text

69. Ghosh $\mathrm{P}$, Amaya M, Mellins $\mathrm{E}$, et al.: The structure of an intermediate in class II MHC maturation: CLIP bound to HLA-DR3. Nature. 1995; 378(6556): 457-62. PubMed Abstract | Publisher Full Text

70. Mellins E, Smith L, Arp B, et al.: Defective processing and presentation of exogenous antigens in mutants with normal HLA class II genes. Nature. 1990; 343(6253): 71-4

PubMed Abstract | Publisher Full Text

71. Sette A, Ceman S, Kubo RT, et al.: Invariant chain peptides in most HLA-DR molecules of an antigen-processing mutant. Science. 1992; 258(5089): 1801-4. PubMed Abstract | Publisher Full Text

72. Sloan VS, Cameron P, Porter G, et al.: Mediation by HLA-DM of dissociation of peptides from HLA-DR. Nature. 1995; 375(6534): 802-6.

PubMed Abstract | Publisher Full Tex

73. Arndt SO, Vogt AB, Hämmerling GJ, et al:: Selection of the MHC class IIassociated peptide repertoire by HLA-DM. Immunol Res. 1997; 16(3): 261-72. PubMed Abstract | Publisher Full Text

74. Chou CL, Sadegh-Nasseri S: HLA-DM recognizes the flexible conformation of major histocompatibility complex class II. J Exp Med. 2000; 192(12): 1697-706. PubMed Abstract | Publisher Full Text | Free Full Text 
75. F Zarutskie JA, Busch R, Zavala-Ruiz Z, et al:: The kinetic basis of peptide exchange catalysis by HLA-DM. Proc Natl Acad Sci U S A. 2001; 98(22): 12450-5. PubMed Abstract | Publisher Full Text | Free Full Text | F1000 Recommendation

76. Belmares MP, Busch R, Mellins ED, et al.: Formation of two peptide/MHC II isomers is catalyzed differentially by HLA-DM. Biochemistry. 2003; 42(3): 838-47. PubMed Abstract | Publisher Full Text

77. Pashine A, Busch R, Belmares MP, et al:: Interaction of HLA-DR with an acidic face of HLA-DM disrupts sequence-dependent interactions with peptides. Immunity. 2003; 19(2): 183-92.

PubMed Abstract | Publisher Full Text

78. Stratikos E, Wiley DC, Stern LJ: Enhanced catalytic action of HLA-DM on the exchange of peptides lacking backbone hydrogen bonds between their $\mathrm{N}$-terminal region and the MHC class II alpha-chain. J Immunol. 2004; 172(2): 1109-17. PubMed Abstract | Publisher Full Text

79. F Nicholson MJ, Moradi B, Seth NP, et al:: Small molecules that enhance the catalytic efficiency of HLA-DM. J Immunol. 2006; 176(7): 4208-20. PubMed Abstract | Publisher Full Text | Free Full Text | F1000 Recommendation

80. F Chou CL, Mirshahidi S, Su KW, et al:: Short peptide sequences mimic HLA-DM functions. Mol Immunol. 2008; 45(7): 1935-43. PubMed Abstract | Publisher Full Text | F1000 Recommendation

81. Sadegh-Nasseri S, Chen M, Narayan K, et al.: The convergent roles of tapasin and HLA-DM in antigen presentation. Trends Immunol. 2008; 29(3): 141-7. PubMed Abstract | Publisher Full Text | Free Full Text

82. Narayan K, Su KW, Chou CL, et al.: HLA-DM mediates peptide exchange by interacting transiently and repeatedly with HLA-DR1. Mol Immunol. 2009; 46(15): 3157-62

PubMed Abstract | Publisher Full Text | Free Full Text

83. Zhou Z, Callaway KA, Weber DA, et al:: Cutting edge: HLA-DM functions through a mechanism that does not require specific conserved hydrogen bonds in class II MHC-peptide complexes. J Immunol. 2009; 183(7): 4187-91. PubMed Abstract | Publisher Full Text | Free Full Text

84. F Anders AK, Call MJ, Schulze MS, et al:: HLA-DM captures partially empty HLA-DR molecules for catalyzed removal of peptide. Nat Immunol. 2011; 12(1): 54-61.

PubMed Abstract | Publisher Full Text | Free Full Text | F1000 Recommendation

85. Jardetzky TS, Gorga JC, Busch R, et al:: Peptide binding to HLA-DR1: a peptide with most residues substituted to alanine retains MHC binding. EMBO J.1990; 9(6): 1797-803.

PubMed Abstract | Free Full Text

86. F Narayan K, Chou CL, Kim A, et al:: HLA-DM targets the hydrogen bond between the histidine at position beta81 and peptide to dissociate HLA-DRpeptide complexes. Nat Immunol. 2007; 8(1): 92-100.

PubMed Abstract | Publisher Full Text | Free Full Text | F1000 Recommendation

87. F Ferrante A, Templeton M, Hoffman M, et al:: The Thermodynamic Mechanism of Peptide-MHC Class II Complex Formation Is a Determinant of Susceptibility to HLA-DM. J Immunol. 2015; 195(3): 1251-61.

PubMed Abstract | Publisher Full Text | Free Full Text | F1000 Recommendation

88. Bikoff EK, Wutz G, Kenty GA, et al.: Relaxed DM requirements during class II peptide loading and $\mathrm{CD4}^{+} \mathrm{T}$ cell maturation in BALB/c mice. $\mathrm{J}$ Immunol. 2001; 166(8): 5087-98.

PubMed Abstract | Publisher Full Text

89. Wolf PR, Tourne S, Miyazaki T, et al:: The phenotype of H-2M-deficient mice is dependent on the MHC class II molecules expressed. Eur J Immunol. 1998; 28(9): 2605-18.

PubMed Abstract | Publisher Full Tex

90. F Pos W, Sethi DK, Call MJ, et al:: Crystal structure of the HLA-DM-HLA-DR1 complex defines mechanisms for rapid peptide selection. Cell. 2012; 151(7): 1557-68.

PubMed Abstract | Publisher Full Text | Free Full Text | F1000 Recommendation

91. F Lovitch SB, Petzold SJ, Unanue ER: Cutting edge: H-2DM is responsible for the large differences in presentation among peptides selected by $1-A^{k}$ during antigen processing. $J$ Immunol. 2003; 171(5): 2183-6.

PubMed Abstract | Publisher Full Text | F1000 Recommendation

92. Sercarz EE, Lehmann PV, Ametani A, et al.: Dominance and crypticity of $\mathrm{T}$ cell antigenic determinants. Annu Rev Immunol. 1993; 11: 729-66. PubMed Abstract | Publisher Full Text

93. Dai G, Steede NK, Landry SJ: Allocation of helper T-cell epitope immunodominance according to three-dimensional structure in the human immunodeficiency virus type I envelope glycoprotein gp120. J Biol Chem. 2001; 276(45): 41913-20.

PubMed Abstract | Publisher Full Text

94. $\mathrm{F}$ Maric M, Arunachalam B, Phan UT, et al:: Defective antigen processing in GILT-free mice. Science. 2001; 294(5545): 1361-5. PubMed Abstract | Publisher Full Text | F1000 Recommendation

95. Hastings $\mathrm{KT}$, Cresswell $\mathrm{P}$ : Disulfide reduction in the endocytic pathway: immunological functions of gamma-interferon-inducible lysosomal thiol reductase. Antioxid Redox Signal. 2011; 15(3): 657-68. PubMed Abstract | Publisher Full Text | Free Full Text

96. West LC, Cresswell P: Expanding roles for GILT in immunity. Curr Opin Immunol. 2013; 25(1): 103-8.

PubMed Abstract | Publisher Full Text | Free Full Text

97. Lee $\mathrm{P}$, Matsueda GR, Allen PM: T cell recognition of fibrinogen. A determinant on the A alpha-chain does not require processing. J Immunol. 1988; 140(4): 1063-8.

PubMed Abstract

98. Nepom GT, Lippolis JD, White FM, et al: Identification and modulation of a naturally processed $\mathrm{T}$ cell epitope from the diabetes-associated autoantigen human glutamic acid decarboxylase 65 (hGAD65). Proc Natl Acad Sci U S A. 2001; 98(4): 1763-8.

PubMed Abstract | Publisher Full Text | Free Full Text

99. Guillet JG, Lai MZ, Briner TJ, et al.: Interaction of peptide antigens and class II major histocompatibility complex antigens. Nature. 1986; 324(6094): 260-2. PubMed Abstract | Publisher Full Text

100. Hartman IZ, Kim A, Cotter RJ, et al.: A reductionist cell-free major histocompatibility complex class II antigen processing system identifies immunodominant epitopes. Nat Med. 2010; 16(11): 1333-40. PubMed Abstract | Publisher Full Text | Free Full Text

101. Sette A, Adorini L, Colon SM, et al:: Capacity of intact proteins to bind to MHC class II molecules. J Immunol. 1989; 143(4): 1265-7. PubMed Abstract

102. Runnels HA, Weber DA, Moore JC, et al.: Intact proteins can bind to class II histocompatibility molecules with high affinity. Mol Immunol. 1997; 34(6): 471-80.

PubMed Abstract | Publisher Full Text

103. Castellino F, Zappacosta F, Coligan JE, et al.: Large protein fragments as substrates for endocytic antigen capture by MHC class II molecules. $J$ Immunol. 1998; 161(8): 4048-57. PubMed Abstract

104. Janway C: Immunobiology. New York \& London: Garland Science; 2008

105. Kim A, Sadegh-Nasseri S: Determinants of immunodominance for CD4 T cells. Curr Opin Immunol. 2015; 34: 9-15. PubMed Abstract | Publisher Full Text | Free Full Text

106. Sadegh-Nasseri S, Kim A: Exogenous antigens bind MHC class II first, and are processed by cathepsins later. Mol Immunol. 2015; 68(2 Pt A): 81-4. PubMed Abstract | Publisher Full Text | Free Full Text

107. F Yin L, Calvo-Calle JM, Dominguez-Amorocho O, et al.: HLA-DM constrains epitope selection in the human CD4 T cell response to vaccinia virus by favoring the presentation of peptides with longer HLA-DM-mediated half-lives. $J$ Immunol. 2012; 189(8): 3983-94.

PubMed Abstract | Publisher Full Text | Free Full Text | F1000 Recommendation

108. Sadegh-Nasseri S, Kim A: MHC Class II Auto-Antigen Presentation is Unconventional. Front Immunol. 2015; 6: 372

PubMed Abstract | Publisher Full Text | Free Full Text

109. Clement CC, Cannizzo ES, Nastke MD, et al:: An expanded self-antigen peptidome is carried by the human lymph as compared to the plasma. PLOS One. 2010; 5(3): e9863.

PubMed Abstract | Publisher Full Text | Free Full Text

110. Clement CC, Rotzschke $O$, Santambrogio $L$ : The lymph as a pool of self-antigens. Trends Immunol. 2011; 32(1): 6-11.

PubMed Abstract | Publisher Full Text | Free Full Text

111. Lovitch SB, Walters JJ, Gross ML, et al:: APCs present $\mathbf{A}$ betak-derived peptides that are autoantigenic to type B T cells. J Immunol. 2003; 170(8): 4155-60. PubMed Abstract | Publisher Full Text

112. F Lovitch SB, Esparza TJ, Schweitzer G, et al: Activation of type B T cells after protein immunization reveals novel pathways of in vivo presentation of peptides. J Immunol. 2007; 178(1): 122-33.

PubMed Abstract | Publisher Full Text | F1000 Recommendation

113. F Mohan JF, Levisetti MG, Calderon B, et al.: Unique autoreactive T cells recognize insulin peptides generated within the islets of Langerhans in autoimmune diabetes. Nat Immunol. 2010; 11(4): 350-4.

PubMed Abstract | Publisher Full Text | Free Full Text | F1000 Recommendation

114. Santambrogio L, Sato AK, Carven GJ, et al.: Extracellular antigen processing and presentation by immature dendritic cells. Proc Natl Acad Sci U S A. 1999; 96(26): 15056-61.

PubMed Abstract | Publisher Full Text | Free Full Text

115. Poluektov YO, Kim A, Sadegh-Nasseri S: HLA-DO and Its Role in MHC Class II Antigen Presentation. Front Immunol. 2013; 4: 260. PubMed Abstract | Publisher Full Text | Free Full Text

116. Poluektov YO, Kim A, Hartman IZ, et al.: HLA-DO as the optimizer of epitope selection for MHC class II antigen presentation. PLOS One. 2013; 8(8): e71228. PubMed Abstract | Publisher Full Text | Free Full Text

117. Denzin LK, Cresswell P: Sibling rivalry: competition between MHC class II family members inhibits immunity. Nat Struct Mol Biol. 2013; 20(1): 7-10. PubMed Abstract | Publisher Full Text

118. Guce Al, Mortimer SE, Yoon T, et al:: HLA-DO acts as a substrate mimic to 
inhibit HLA-DM by a competitive mechanism. Nat Struct Mol Biol. 2013; 20(1): 90-8

PubMed Abstract | Publisher Full Text | Free Full Text

119. Darrah E, Rosen A, Giles JT, et al.: Peptidylarginine deiminase 2, 3 and 4 have distinct specificities against cellular substrates: novel insights into autoantigen selection in rheumatoid arthritis. Ann Rheum Dis. 2012; 71(1): 92-8. PubMed Abstract | Publisher Full Text | Free Full Text

120. Doolan DL, Southwood S, Freilich DA, et al.: Identification of Plasmodium falciparum antigens by antigenic analysis of genomic and proteomic data. Proc Natl Acad Sci U S A. 2003; 100(17): 9952-7. PubMed Abstract | Publisher Full Text | Free Full Text

121. Rammensee H, Bachmann J, Emmerich NP, et al:: SYFPEITHI: database for MHC ligands and peptide motifs. Immunogenetics. 1999; 50(3-4): 213-9. PubMed Abstract | Publisher Full Text

122. Peters HO, Mendoza MG, Capina RE, et al.: An integrative bioinformatic approach for studying escape mutations in human immunodeficiency virus type 1 gag in the Pumwani Sex Worker Cohort. J Virol. 2008; 82(4): 1980-92. PubMed Abstract | Publisher Full Text | Free Full Text

123. Henderson RA, Michel H, Sakaguchi K, et al:: HLA-A2.1-associated peptides from a mutant cell line: a second pathway of antigen presentation. Science. 1992; 255(5049): 1264-6.

PubMed Abstract | Publisher Full Text

124. F Clement CC, Becerra A, Yin L, et al.: The Dendritic Cell Major Histocompatibility Complex II (MHC II) Peptidome Derives from a Variety of Processing Pathways and Includes Peptides with a Broad Spectrum of HLADM Sensitivity. J Biol Chem. 2016; 291(11): 5576-95.

PubMed Abstract | Publisher Full Text | Free Full Text | F1000 Recommendation

125. F Ong SE: Whole proteomes as internal standards in quantitative proteomics. Genome Med. 2010; 2(7): 49.

PubMed Abstract | Publisher Full Text | Free Full Text | F1000 Recommendation 


\section{Open Peer Review}

\section{Current Peer Review Status:}

\section{Editorial Note on the Review Process}

Faculty Reviews are review articles written by the prestigious Members of Faculty Opinions. The articles are commissioned and peer reviewed before publication to ensure that the final, published version is comprehensive and accessible. The reviewers who approved the final version are listed with their names and affiliations.

\section{The reviewers who approved this article are:}

\section{Version 1}

1. Laura Santambrogio

1 Department of Pathology, Albert Einstein College of Medicine, New York, New York, 10461, USA

2 Department of Microbiology \& Immunology, Albert Einstein College of Medicine, New York, New York, 10461, USA Competing Interests: No competing interests were disclosed.

\section{Bénédicte Manoury} INEM, U1151-CNRS UMR 8253, Faculté de Médecine, Université Paris Descartes, Sorbonne Paris Cité, Paris, 75015, France

Competing Interests: No competing interests were disclosed.

\section{Nilabh Shastri}

Division of Immunology and Pathogenesis, Department of Molecular and Cell Biology, University of California, Berkeley, California, 94720, USA

Competing Interests: No competing interests were disclosed.

\section{Malini Raghavan (iD)}

Department of Microbiology and Immunology, University of Michigan Medical School, Ann Arbor, MI, 48109, USA

Competing Interests: No competing interests were disclosed. 
The benefits of publishing with F1000Research:

- Your article is published within days, with no editorial bias

- You can publish traditional articles, null/negative results, case reports, data notes and more

- The peer review process is transparent and collaborative

- Your article is indexed in PubMed after passing peer review

- Dedicated customer support at every stage

For pre-submission enquiries, contact research@f1000.com 